\title{
Sunlight modulates the relative importance of heterotrophic bacteria and picophytoplankton in DMSP-sulphur uptake
}

\author{
Clara Ruiz-González ${ }^{1}$, Rafel Simó ${ }^{1}$, Maria Vila-Costa ${ }^{2}$, Ruben Sommaruga $^{3}$ \\ and Josep M Gasol ${ }^{1}$ \\ ${ }^{1}$ Institut de Ciències del Mar-CSIC, Barcelona, Catalunya, Spain; ${ }^{2}$ Department of Continental \\ Ecology-Limnology, Centre d'Estudis Avançats de Blanes-CSIC, Blanes, Catalunya, Spain and ${ }^{3}$ Laboratory of \\ Aquatic Photobiology and Plankton Ecology, Institute of Ecology, University of Innsbruck, Innsbruck, Austria
}

\begin{abstract}
There is a large body of evidence supporting a major role of heterotrophic bacteria in dimethylsulphoniopropionate (DMSP) utilisation as a source of reduced sulphur. However, a role for phototrophic microorganisms has been only recently described and little is known about their contribution to DMSP consumption and the potential modulating effects of sunlight. In an attempt to ascertain the relative quantitative roles of heterotrophic bacteria and picophytoplankton in the osmoheterotrophic uptake of DMSP-sulphur upon exposure to natural sunlight conditions, we incubated northwestern Mediterranean waters under various optical filters and used an array of bulk and single-cell activity methods to trace the fate of added ${ }^{35}$ S-DMSP. Flow cytometry cell sorting confirmed dark ${ }^{35} \mathrm{~S}$ uptake by Prochlorococcus, Synechococcus and heterotrophic bacteria, the latter being the most efficient in terms of uptake on a cell volume basis. Under exposure to full sunlight, however, the relative contribution of Synechococcus was significantly enhanced, mainly because of the inhibition of heterotrophic bacteria. Microautoradiography showed a strong increase in the proportion of Synechococcus cells actively taking up ${ }^{35} \mathrm{~S}-\mathrm{DMSP}$, which, after full sunlight exposure, made up to $15 \%$ of total active Bacteria. Parallel incubations with ${ }^{3} \mathrm{H}$-leucine generally showed no clear responses to light. Finally, size-fractionated assimilation experiments showed greater relative cyanobacterial assimilation during the day than at night compared with that of heterotrophic bacteria. Our results show for the first time a major influence of sunlight in regulating the competition among autotrophic and heterotrophic picoplankton for DMSP uptake at both the daily and seasonal time scales.
\end{abstract}

The ISME Journal (2012) 6, 650-659; doi:10.1038/ismej.2011.118; published online 29 September 2011

Subject Category: microbial ecology and functional diversity of natural habitats

Keywords: dimethylsulphoniopropionate; leucine; heterotrophic bacteria; NW Mediterranean; picophytoplankton; solar radiation

\section{Introduction}

Dimethylsulphide (DMS) is a biogenic volatile compound that is universally present in sea water (Lovelock et al., 1972; Kettle et al., 1999) and represents the major natural source of sulphur to the global troposphere (Bates et al., 1992; Andreae and Crutzen, 1997). The biogeochemical significance of DMS was first suggested when its emissions were found to be a key step in the global sulphur cycle (Lovelock et al., 1972), and research was further encouraged when marine plankton was proposed to play a significant role in climate

Correspondence: C Ruiz-González, Institut de Ciències del Mar-CSIC, Passeig Marítim de la Barceloneta 37-49, Barcelona, Catalunya 08003, Spain.

E-mail: clara.ruiz.glez@gmail.com

Received 7 February 2011; revised 25 July 2011; accepted 28 July 2011; published online 29 September 2011 regulation through the effects of DMS emissions on cloud formation (Charlson et al., 1987).

The biochemical precursor of DMS is dimethylsulphoniopropionate (DMSP), an osmolyte produced by many phytoplankton taxa and released into the dissolved organic matter pool through grazing, viral lysis, algal autolysis or exudation (Stefels, 2000; Simó, 2001). Once in sea water, DMSP may become available as a significant source of carbon and sulphur for other planktonic organisms. Released dissolved DMSP also acts as a direct or indirect (by transformation into DMS) chemical signal for plankton microbes (Seymour et al., 2010), marine invertebrates, fish, birds and mammals (Van Alstyne et al., 2001; Cunningham et al., 2008; DeBose et al., 2008; Nevitt, 2008).

Among the marine organisms directly utilising DMSP, heterotrophic bacteria have been the most extensively studied (Kiene et al., 1999; Simó et al., 2002; Howard et al., 2006; Vila-Costa et al., 2007) 
and their capacity to assimilate sulphur from DMSP appears to be widespread among different taxonomic groups (see, for example, González et al., 1999; Malmstrom et al., 2004a; Vila-Costa et al., 2008b; Ruiz-González et al., 2011). Actually, bacterial uptake of dissolved DMSP and partial assimilation of its sulphur is thought to be the dominant mechanism for DMSP degradation in the pelagic ocean (Kiene et al., 2000; Zubkov et al., 2002). Other transformation processes include cleavage into DMS and carbon products mediated by the DMSP producers themselves and bacteria (Stefels, 2000; Sunda et al., 2002), accumulation or assimilation by zooplankton grazing on phytoplankton (Dacey and Wakeham, 1986; Archer et al., 2003; Tang and Simó, 2003; Saló et al., 2009) and direct uptake and assimilation by eukaryotic phytoplankton (Vila-Costa et al., 2006; Ruiz-González et al., submitted) and cyanobacteria (Malmstrom et al., 2005; Vila-Costa et al., 2006).

Among the aforementioned transformation processes, little is known about the quantitative role of non-DMSP-producing photosynthetic organisms. Because of their autotrophic lifestyle, the contribution of phytoplankton to the turnover of DMSP was expected to be minimal, but Synechococcus were reported to be major consumers of DMSP and methanethiol with contributions comparable to other bacterial groups (Malmstrom et al., 2005). Similarly, Prochlorococcus, diatoms and photosynthetic picoeukaryotes are also able to take up and assimilate a remarkable fraction of DMSP (Vila-Costa et al., 2006), suggesting that in the appropriate circumstances, they could compete with heterotrophic bacteria for this substrate.

An important implication of DMSP utilisation by phytoplankton is the possible effect of light on DMSP consumption processes. As algae are affected by variations in energy supply because of changes in the quantity and quality of light available, processes such as DMSP-sulphur assimilation may also be coupled to this periodicity. Only in two studies has light been shown to affect the assimilation of DMSPsulphur by phototrophs, providing variable degrees of light-driven stimulation of the uptake (Malmstrom et al., 2005; Vila-Costa et al., 2006). Therefore, light may be playing an important role in regulating the relative contributions of heterotrophic and phototrophic uptake to total DMSP consumption. So far, however, experiments had been conducted in the absence of ultraviolet radiation (UVR, $280-400 \mathrm{~nm})$, and hence it is likely that the contribution of phytoplankton relative to that of heterotrophic bacterioplankton (generally less UVR protected) had been underestimated. UVR has recently been found to be a significant factor modifying the fate of DMSP through either inhibition of microbial consumption (Slezak et al., 2001, 2007) or stimulation of its production, release (Sunda et al., 2002; Slezak and Herndl, 2003; Archer et al., 2010) or uptake by autotrophs (Malmstrom et al., 2005; Vila-Costa et al., 2006; Ruiz-González et al., submitted). Incubations under natural sunlight conditions are necessary to properly assess the shares of the different components of the microbial food web in the use of this widespread substrate.

Our aim in this study was to assess for the first time the role of sunlight, including UVR, in DMSP uptake by picoplankton through experiments conducted with plankton communities sampled at the Blanes Bay Microbial Observatory and adjacent offshore waters of the northwestern Mediterranean. We used an array of multiple bulk and specific activity methods including flow cytometry cell sorting, size-fractionated assimilation and microautoradiography combined with RNA probing after samples were exposed to different light spectrum conditions. As sunlight has the potential to trigger the autotrophic activity and simultaneously inhibit heterotrophic bacterial activity, our hypothesis was that exposure to enhanced natural solar radiation would favour picophytoplankton in their competition for DMSP uptake against heterotrophic bacteria.

\section{Materials and methods}

Study area and sample collection

Water samples were collected either from a shallow (20 m depth) coastal station (the Blanes Bay Microbial Observatory (BBMO)) located $800 \mathrm{~m}$ offshore or during a cruise aboard the RV 'García del Cid' between 18 and 26 September 2007 at two stations, one located on the continental shelf in the vicinity of the BBMO (station $\mathrm{C}$ ) and another one offshore over a $2000 \mathrm{~m}$ deep-water column between the BBMO and Mallorca (northwestern Mediterranean, Table 1). Surface samples $(0.5 \mathrm{~m})$ from the BBMO were collected with a Niskin Go-flow bottle (5 l), prefiltered through a $200 \mu \mathrm{m}$-mesh size net, and transported under dim light to the lab for the three experiments carried out on 5 August 2003 (experiment (exp.) 2), 9 July 2008 and 30 September 2008 (exps. 3 and 4, respectively). Water samples during the cruise (4 or $48 \mathrm{~m}$ depth) were taken with a 12-Niskin-bottle rosette attached to the CTD (conductivity, temperature, depth recorder; exps. 1, 5 and 6).

\section{Experimental design}

Different types of incubations were carried out with added trace ${ }^{35}$ S-DMSP, kindly donated by RP Kiene (University of South Alabama, Dauphin Island Sea Lab, Dauphin Island, AL, USA). At several occasions, parallel incubations with ${ }^{3} \mathrm{H}$-leucine (Amersham, Piscataway, NJ, USA; $161 \mathrm{Ci} \mathrm{mmol}^{-1}$ ) were also done for comparative purposes as it is widely used as a measurement of bacterial heterotrophic production (Kirchman et al., 1985). Only in exps. 3 and 4 , the photosynthetic active radiation (PAR) and UVR doses were monitored during incubations with a PUV-2500 radiometer 
Table 1 Sampling locations, methodology and date of each experiment

\begin{tabular}{|c|c|c|c|c|c|c|c|c|c|c|}
\hline Station & Exp. & Techniques & $\begin{array}{c}\text { Date } \\
\text { (day/month } \\
\text { /year) }\end{array}$ & Longitude & Latitude & $\begin{array}{l}\text { Depth } \\
\text { (m) }\end{array}$ & $\begin{array}{c}H B \\
\left(10^{5} \text { per ml }\right)\end{array}$ & $\begin{array}{c}\text { Syn } \\
\left(10^{4} \text { per ml) }\right.\end{array}$ & $\begin{array}{c}\text { Prochl } \\
\left(10^{4} \text { per } \mathrm{ml}\right)\end{array}$ & $\begin{array}{c}U V B \\
\left(k J m^{-2}\right)\end{array}$ \\
\hline $\mathrm{D}$ & 1 & Sorting (dark) & $24 / 09 / 07$ & $2^{\circ} 51.06^{\prime} \mathrm{E}$ & $40^{\circ} 39.60^{\prime} \mathrm{N}$ & 48 & 6.9 & 2.1 & 17.8 & - \\
\hline BBMO & 2 & Sorting (light) & 05/08/03 & $2^{\circ} 48.03^{\prime} \mathrm{E}$ & $41^{\circ} 39.90^{\prime} \mathrm{N}$ & 0.5 & 8.5 & 7.2 & 0.2 & 21.0 \\
\hline BBMO & 3 & MAR-CARD-FISH & 09/07/08 & $2^{\circ} 48.03^{\prime} \mathrm{E}$ & $41^{\circ} 39.90^{\prime} \mathrm{N}$ & 0.5 & 8.5 & 2.3 & - & 22.0 \\
\hline BBMO & 4 & MAR-CARD-FISH & $30 / 09 / 08$ & $2^{\circ} 48.03^{\prime} \mathrm{E}$ & $41^{\circ} 39.90^{\prime} \mathrm{N}$ & 0.5 & 7.2 & 4.7 & 3 & 11.3 \\
\hline $\mathrm{C}$ & 5 & Diel cycle (Assim) & $18-19 / 09 / 07$ & $2^{\circ} 47.58^{\prime} \mathrm{E}$ & $41^{\circ} 40.08^{\prime} \mathrm{N}$ & 4 & 4.8 & 0.5 & 0.4 & - \\
\hline $\mathrm{D}$ & 6 & Diel cycle (Assim) & $23-24 / 09 / 07$ & $2^{\circ} 51.06^{\prime} \mathrm{E}$ & $40^{\circ} 39.60^{\prime} \mathrm{N}$ & 4 & 6.0 & 1.5 & 1.3 & - \\
\hline
\end{tabular}

Abbreviations: Assim, size-fractionated ${ }^{35} \mathrm{~S}$ assimilation from added ${ }^{35} \mathrm{~S}-\mathrm{DMSP}$; BBMO, Blanes Bay Microbial Observatory; MAR-CARD-FISH, microautoradiography combined with catalysed reporter deposition-fluorescence in situ hybridisation. The abundances of heterotrophic bacteria (HB), Synechococcus (Syn) and Prochlorococcus (Prochl) are given for the initial water sample. Integrated ultraviolet B (UVB) radiation during experiments were determined with a PUV radiometer (exps. 3 and 4) or estimated from the irradiance values collected at the Malgrat de Mar meteorological station (exp. 1, see Materials and methods).

(Biospherical Instruments, San Diego, CA, USA). In exp. 1, UVB levels were estimated from the irradiance values obtained from a meteorological station located $5 \mathrm{~km}$ southwest from the BBMO sampling station (Malgrat de Mar, Catalan Meteorological Service, SCM). The UVB doses are shown in Table 1.

Exp. 1: dark incubation for cell sorting. Water was collected around midnight from $48 \mathrm{~m}$ depth at the offshore station $\mathrm{D}$. This was the depth where the cell abundance of Prochlorococcus $\left(1.8 \times 10^{5}\right.$ cells per $\mathrm{ml}$; Table 1) was large enough to allow sorting. A single $50 \mathrm{ml}$ sample was amended with ${ }^{35} \mathrm{~S}$-DMSP (815 $\mathrm{Ci} \mathrm{mmol}^{-1}, 0.03 \mathrm{nM}$ final concentration (conc.)) and incubated in the dark for $6 \mathrm{~h}$ at in situ temperature (ca. $17^{\circ} \mathrm{C}$ ). After exposure, $5 \mathrm{ml}$ subsamples were fixed with $1 \%$ paraformaldehyde (PFA) $+0.05 \%$ glutaraldehyde (final conc.), flash-frozen in liquid nitrogen and stored at $-80^{\circ} \mathrm{C}$. Killed controls were prepared by addition of the fixative $30 \mathrm{~min}$ before the addition of the radioisotope, and were simultaneously incubated with the live samples.

Exps. 2-4: light manipulation experiments. Spherical quartz glass bottles of 50 or $100 \mathrm{ml}$ were used to incubate surface water samples $(0.5 \mathrm{~m}$ depth) collected in the Blanes Bay for $4 \mathrm{~h}$ under different light conditions. In exps. 3 and 4, samples were amended with trace ${ }^{35} \mathrm{~S}$-DMSP (453 and $23 \mathrm{Cimmol}^{-1}, 0.08$ and $1 \mathrm{nM}$ final conc., respectively) or ${ }^{3} \mathrm{H}$-leucine (161 Ci mmol ${ }^{-1}, 0.5 \mathrm{nM}$ final conc.) immediately before exposure, whereas in exp. 2, they were added after the light incubations. In this experiment (no. 2), the conditions were: (1) full sunlight spectrum; (2) full spectrum minus UVB; (3) full spectrum minus the whole of UVR, that is, PAR only; and (4) darkness (wrapped with aluminium foil inside a black plastic bag). In exps. 3 and 4, the conditions were the same except for that treatment (2) was excluded. For the removal of UVB radiation (that is, PAR + UVA treatment), one layer of the plastic foil Mylar-D (150 $\mu \mathrm{m}$ thickness, $50 \%$ transmission at $325 \mathrm{~nm}$ ) was used. For PAR-only treatments, bottles from exp. 2 were wrapped with one layer of a vinyl chloride foil ( $50 \%$ transmittance at $405 \mathrm{~nm}$; CI Kasei Co., Tokyo, Japan), and bottles from exps. 3 and 4 were covered with two layers of Ultraphan URUV (0.1 mm thickness, 50\% transmittance at $380 \mathrm{~nm}$; Digefra, Munich, Germany). All bottles were incubated $4 \mathrm{~cm}$ below the water surface inside a black tank with circulating sea water to maintain in situ temperature. After sunlight exposure, $50-100 \mathrm{ml}$ subsamples from exp. 2 were incubated for $4 \mathrm{~h}$ with trace additions of ${ }^{35} \mathrm{~S}$-DMSP $\left(0.1 \mathrm{nM}, \quad\right.$ specific activity $\left.130-350 \mathrm{Ci} \mathrm{mmol}^{-1}\right)$ or ${ }^{3} \mathrm{H}$-leucine (161 $\mathrm{Ci} \mathrm{mmol}^{-1}, 0.5 \mathrm{nM}$ final conc.) in the dark in acid-cleaned glass serum vials. Samples were fixed with $1 \%$ PFA $+0.05 \%$ glutaraldehyde (final conc.), flash-frozen in liquid nitrogen and stored at $-80{ }^{\circ} \mathrm{C}$. Live samples from exps. 3 and 4 were fixed overnight with PFA ( $1 \%$ final conc.) at $4{ }^{\circ} \mathrm{C}$ in the dark. Aliquots of $10-15 \mathrm{ml}$ were filtered through $0.22 \mu \mathrm{m}$ polycarbonate filters (GTTP, Millipore Iberica, Madrid, Spain), rinsed with milli-Q water, air dried and stored at $-20^{\circ} \mathrm{C}$ until processing.

Exps. 5 and 6: day/night cycles. During the September 2007 cruise, two diel cycle studies of the assimilation of ${ }^{35} \mathrm{~S}$-DMSP by different size fractions were conducted. For that purpose, $50 \mathrm{ml}$ surface water samples (4 $\mathrm{m}$ depth) were collected every $4 \mathrm{~h}$ during two $24 \mathrm{~h}$ periods and trace concentrations of ${ }^{35} \mathrm{~S}$-DMSP $\left(815 \mathrm{Ci} \mathrm{mmol}^{-1}, 0.8 \mathrm{pM}\right.$ final conc.) were added. Samples were then incubated in $50 \mathrm{ml}$ quartz flasks with the radioisotope for $6 \mathrm{~h}$ at in situ light and temperature conditions inside a black tank with circulating sea water. Killed controls were prepared in $30 \mathrm{ml}$ Teflon flasks by adding PFA (1\% final conc.) before the addition of the radioisotope. After exposure, the incorporation of substrate was stopped by fixing samples overnight with PFA (1\% final conc.) at $4{ }^{\circ} \mathrm{C}$ in the dark.

\section{Flow cytometry cell sorting}

In exps. 1 and 2, different populations were identified and sorted using a FACSCalibur flow cytometer-cell sorter (Becton Dickinson, Franklin Lakes, NJ, USA). Sorted cells were collected onto 
$0.2 \mu \mathrm{m}$ nylon filters and assayed by liquid scintillation counting. We used the 'single cell sort' mode of the instrument and sorted between 100000 and 400000 heterotrophic bacteria, between 30000 and 130000 Synechococcus and between 30000 and 90000 Prochlorococcus (the latter in exp. 1 only). Assimilation of ${ }^{35} \mathrm{~S}$ or ${ }^{3} \mathrm{H}$-leucine in killed samples was $2-3 \%$ of the value in live samples.

\section{Microautoradiography combined with catalysed reporter deposition-fluorescence in situ hybridisation (MAR-CARD-FISH)}

Filters with retained cells from exps. 3 and 4 were hybridised following the CARD-FISH protocol (Pernthaler et al., 2002). Two horseradish peroxidase probes were used to specifically identify most Eubacteria (Eub338-II-III, Amann et al., 1990; Daims et al., 1999) and the cyanobacterial genus Synechococcus (Syn405, West et al., 2001). Hybridisations were done on sections of the filters at $35{ }^{\circ} \mathrm{C}$ overnight. Smaller pieces from each hybridised section were cut and stained with 4,6-diamidino-2phenylindole (DAPI, $1 \mu \mathrm{g} \mathrm{ml}^{-1}$ ) to estimate the relative abundance of each group before applying the microautoradiography, for which 500-1900 DAPI-stained cells were manually counted within 10 to 25 fields. For microautoradiography, we followed the protocol described in Vila-Costa et al. (2007) and filters were exposed inside black boxes at $4{ }^{\circ} \mathrm{C}$ until development (3 days for ${ }^{3} \mathrm{H}$-leucine and ${ }^{35} \mathrm{~S}$-DMSP in exp. 3 , and 5 days for ${ }^{3} \mathrm{H}$-leucine and 7 days for ${ }^{35}$ S-DMSP in exp. 4). Slides were developed as previously reported (Vila-Costa et al., 2007), stained with DAPI $\left(1 \mu \mathrm{g} \mathrm{ml}^{-1}\right)$ and $500-700$ hybridised cells were counted manually under an epifluorescence microscope.

\section{Isotope assimilation during incubations}

Triplicate aliquots of samples from exps. 5 and 6 (previously prefiltered through $3 \mu \mathrm{m}$ pore-sized filters to exclude larger organisms; SSWP, Millipore) were sequentially filtered through 0.65 and $0.2 \mu \mathrm{m}$ poresized filters (DAWP and GNWP, respectively; Millipore) and rinsed with $0.2 \mu \mathrm{m}$ filtered sea water. Macromolecules were precipitated by treating filters with $5 \mathrm{ml}$ of cold trichloroacetic acid $5 \%$ for $5 \mathrm{~min}$. The filters were then rinsed with milli-Q water, placed into $5 \mathrm{ml}$ of scintillation cocktail (Optiphase HiSafe 2, Perkin Elmer, Madrid, Spain) and counted with a Beckman scintillation counter (Beckman Coulter Inc., Barcelona, Spain). Incorporation of ${ }^{35}$ S-DMSP and ${ }^{3} \mathrm{H}$-leucine in PFA-killed controls was always $<1.5 \%$ of that in live samples.

\section{Results}

Flow cytometry cell sorting of samples exposed to fractional sunlight (exps. 1 and 2)

Flow cytometry cell sorting of samples amended with ${ }^{35} \mathrm{~S}$-DMSP was used to investigate the relative role of heterotrophic bacteria and cyanobacteria in the uptake of DMSP-sulphur. Exps. 1 and 2 were conducted with water from the offshore station D and the coastal BBMO site, respectively. Among cyanobacteria, Synechococcus occurred in high numbers at both stations, but Prochlorococcus only occurred in sufficient numbers at a depth of ca. $50 \mathrm{~m}$ in station D, exp. 1 (Table 1). Cell sorting in this experiment showed that heterotrophic bacteria, Prochlorococcus and Synechococcus had the capability of assimilating ${ }^{35} \mathrm{~S}$ from DMSP (Figure 1a). On a per-cell basis, the most important DMSPsulphur assimilators were Synechococcus (Figure 1b), which showed 8 times more disintegrations per minute (d.p.m.) per cell than heterotrophic bacteria. However, when these values were normalised to total cell volume (assuming a volume ratio $\mathrm{HB} /$ Prochl/ Syn $=1: 5: 10$ ), heterotrophic bacteria were the most relevant consumers of ${ }^{35} \mathrm{~S}$-DMSP followed by Synechococcus and Prochlorococcus (Figure 1c).

Incubation of samples from the Blanes Bay under increasing short-wave radiation doses (exp. 2, Figure 2) resulted in a significant reduction of the contribution of heterotrophic bacteria to total ${ }^{35}$ S-DMSP uptake (Tukey's test, $P<0.05$ ), from $84 \%$ in the dark to $17 \%$ after full sunlight exposure. Conversely, Synechococcus did not seem to be negatively affected by full sunlight exposure, and even a slight photostimulation of their uptake was apparent, yet not significant at $P<0.05$ (Figure 2a).
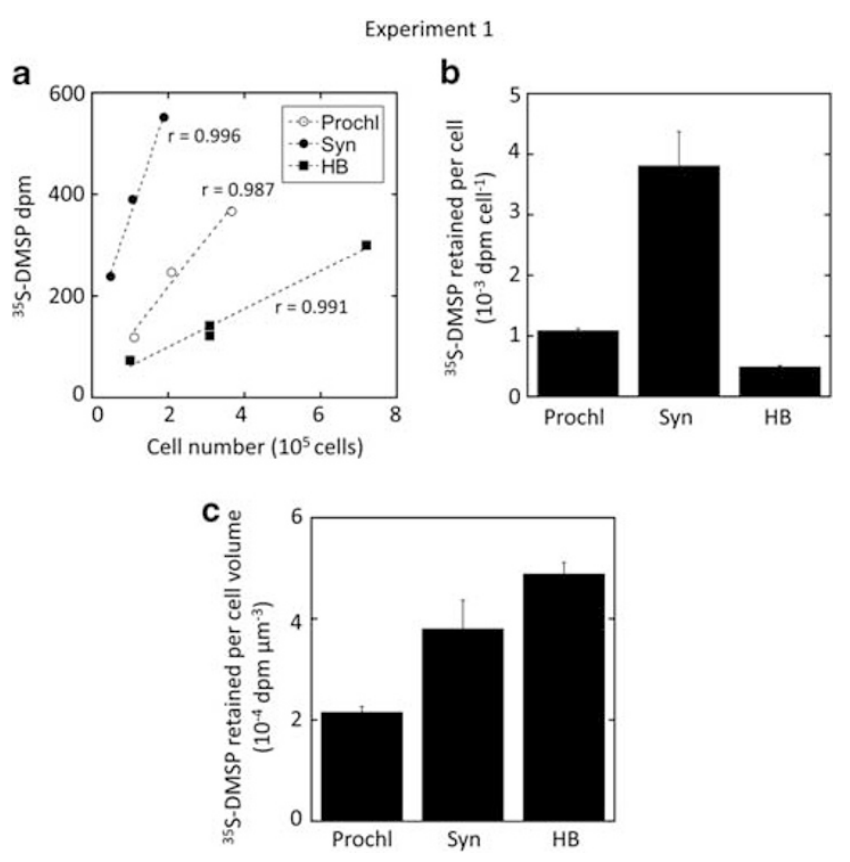

Figure 1 Experiment 1. (a) ${ }^{35}$ S-DMSP retained in cells (d.p.m.) as a function of the number of sorted cells: Prochlorococcus (Prochl), Synechococcus (Syn) and heterotrophic bacteria (HB). (b) Average ${ }^{35}$ S-DMSP retained per cell (d.p.m. per cell). (c) Same as (b) but scaled to cell volume (d.p.m. per $\mu \mathrm{m}^{3}$ ), assuming that Prochlorococcus and Synechococcus are 5 and 10 times larger, respectively, than heterotrophic bacteria. Shown are means \pm standard errors. 
654
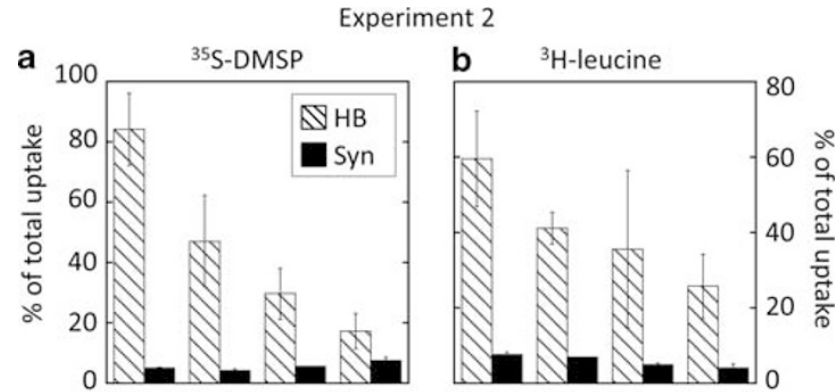

C

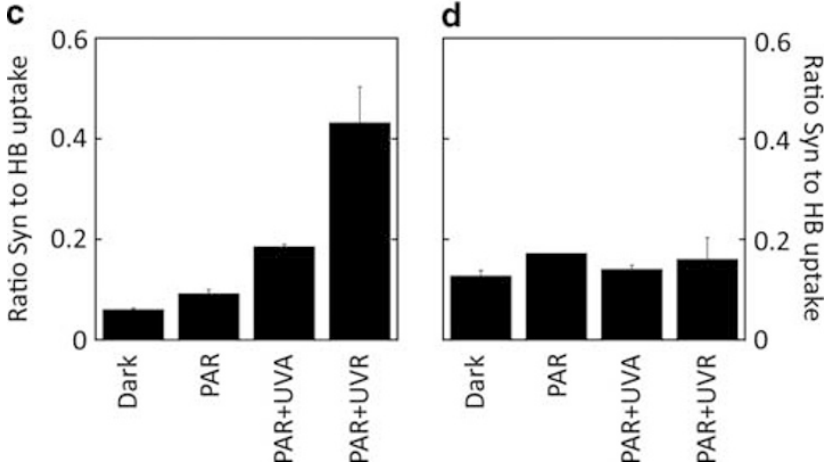

Figure 2 Experiment 2. (Top panels) Contribution of sorted heterotrophic bacteria and Synechococcus cells to total uptake of (a) ${ }^{35} \mathrm{~S}$-DMSP or (b) ${ }^{3} \mathrm{H}$-leucine under different light conditions. Shown are means \pm standard errors. (Bottom panels) Ratio between the contribution of Synechococcus (Syn) and heterotrophic bacteria (HB) to total uptake of (c) ${ }^{35} \mathrm{~S}$-DMSP or (d) ${ }^{3} \mathrm{H}$-leucine.

As a result, the contribution of Synechococcus relative to that of heterotrophic bacteria increased after full sunlight (PAR + UVR) exposure up to sevenfold (Figure 2c), accounting for $40 \%$ of the heterotrophic bacterial ${ }^{35} \mathrm{~S}$-DMSP uptake. The fraction of assimilated ${ }^{35}$ S-DMSP that was not retained by Synechococcus or by heterotrophic bacteria showed an increased contribution to total uptake toward the full spectrum (reaching up to $75 \%$ under PAR + UVR; Figure 2a); yet, we did not specifically analysed which organisms were responsible for this uptake.

When we further assessed the role of light on the efficiency of ${ }^{35} \mathrm{~S}$-DMSP uptake per cell volume, the differences were even greater (Figure 3). Exposure to full sunlight caused a drastic decrease in the d.p.m. per $\mu \mathrm{m}^{3}$ in heterotrophic bacteria to the extent that they equalled those of Synechococcus (Figure 3a). Therefore, under full sunlight, Synechococcus cells seemed to be, on average, as efficient in taking up ${ }^{35} \mathrm{~S}$-DMSP as the average heterotrophic bacterium, as shown by the high ratio between the uptake per unit of cell volume of Synechococcus and heterotrophic bacteria (Figure $3 b$ ).

With ${ }^{3} \mathrm{H}$-leucine as the added substrate, a decreasing trend in the uptake by both Synechococcus and heterotrophic bacteria in all light treatments was observed, although for the latter it was not significant at $P<0.05$ (Figure 2b). The resulting pattern of the relative contributions was essentially invariable with the sunlight spectrum (Figure 2d).

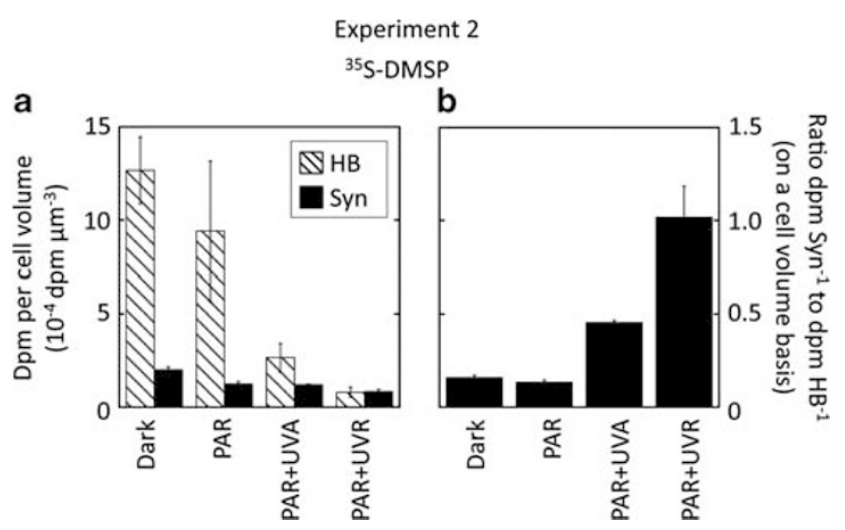

Figure 3 Experiment 2. (a) Comparison of ${ }^{35}$ S-DMSP retained per cell volume (d.p.m. per $\mu \mathrm{m}^{3}$ ) between heterotrophic bacteria and Synechococcus under different light conditions. Values are means \pm standard errors. (b) Ratio between the ${ }^{35}$ S-DMSP uptakes per cell volume of Synechococcus (Syn) and heterotrophic bacteria (HB) under different light conditions.

\section{Single-cell assessment of ${ }^{35} S$-DMSP and ${ }^{3} H$-leucine uptake by MAR-CARD-FISH}

The specific differences in the sensitivity to light of heterotrophic bacteria and Synechococcus were further assessed by applying the MAR-CARD-FISH technique to samples from the BBMO (exps. 3 and 4). Hybridisation with specific probes showed that Bacteria accounted for $88 \%$ and $67 \%$ of total DAPI counts in exps. 3 (summer) and 4 (autumn), respectively, whereas only $1 \%$ and $4 \%$ were Synechococcus (Ruiz-González, unpublished). When samples of the exp. 3 amended with ${ }^{35} \mathrm{~S}$ DMSP were exposed to the different light conditions (Figure 4a), the number of Bacteria active at ${ }^{35} \mathrm{~S}$ uptake significantly decreased upon full sunlight exposure compared with both dark and PAR treatments (Tukey's test, $P<0.05$ ), whereas the number of active Synechococcus strongly increased from ca. $10 \%$ to up to $80 \%$, reaching $15 \%$ of total active Bacteria after full sunlight exposure (Figure 5a) when multiplied by their abundances. In exp. 4, conversely, both Bacteria and Synechococcus were stimulated in their ${ }^{35} \mathrm{~S}$ uptake upon exposure to light (Figure 4b); however, the increase of Synechococcus (by eightfold) was much greater than that of bacteria, which resulted in a light-driven increased contribution of the former to the total numbers of cells active in ${ }^{35} \mathrm{~S}$ uptake (Figure $5 \mathrm{~b}$ ).

The number of Bacteria active in the uptake of ${ }^{3} \mathrm{H}$-leucine in both experiments remained unaffected by light conditions, showing high percentages $(70-80 \%)$ all through incubations (Figures $4 \mathrm{c}$ and d). Similarly, Synechococcus from the autumn experiment (exp. 4) were not affected by solar radiation levels (Figure 4d), whereas in the summer (exp. 3) they were stimulated by PAR exposure compared with darkness. Inclusion of UVR caused a subsequent $30 \%$ decrease in the number of active cells (all differences being significant according to the Tukey's test, $P<0.05$; Figure 4c). 


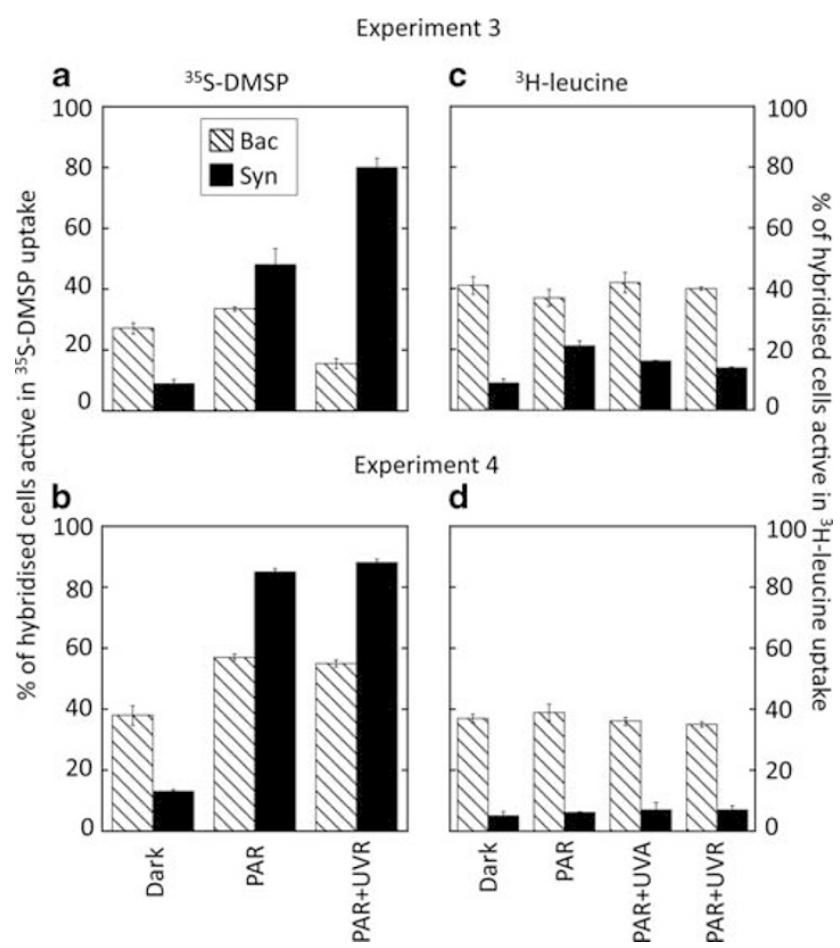

Figure 4 Experiments 3 (top panels) and 4 (bottom panels). Percentage of Bacteria (Bac) and Synechococcus (Syn) cells taking up ${ }^{35} \mathrm{~S}$-DMSP $(\mathbf{a}, \mathbf{b})$ or ${ }^{3} \mathrm{H}$-leucine $(\mathbf{c}, \mathbf{d})$ as quantified by MARCARD-FISH after exposure to different light conditions. ${ }^{35} \mathrm{~S}$-DMSP incubations lacked the PAR + UVA treatment.

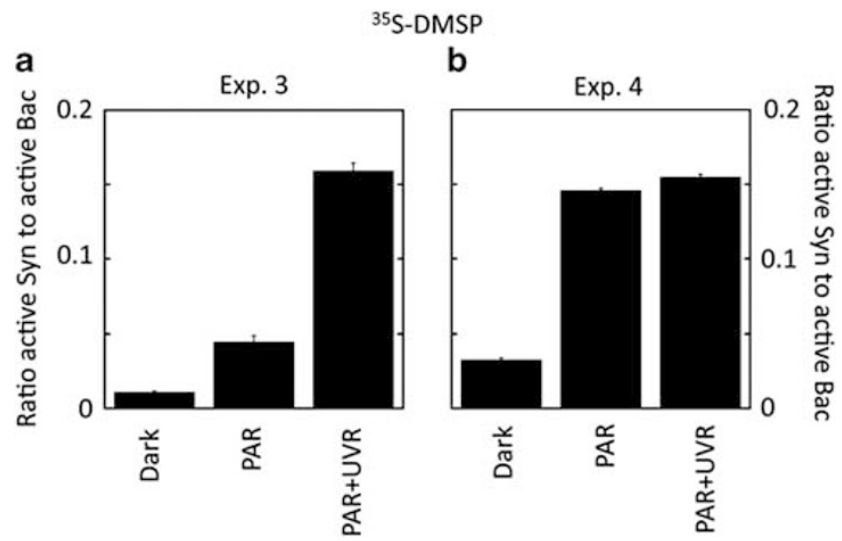

Figure 5 Experiments 3 (a) and 4 (b). Ratio between the total number of active Synechococcus (Syn) and the total number of active Bacteria (Bac) in ${ }^{35}$ S-DMSP uptake upon different light conditions. Values were calculated by multiplying the percentage of active cells within each group by their total abundances.

Diel variation in the bulk assimilation of ${ }^{35} S$-DMSP by size-fractionated plankton

A further assessment of the relative uptake and assimilation of ${ }^{35} \mathrm{~S}$-DMSP was conducted by size-fractionating samples through 0.65 and $0.22 \mu \mathrm{m}$ filters, both after prefiltration through $3 \mu \mathrm{m}$. Results were subtracted to calculate the contribution of organisms sized either $0.65-3 \mu \mathrm{m}$ (mostly cyanobacteria and picoeukaryotes) or $0.22-0.65 \mu \mathrm{m}$ (mostly heterotrophic bacteria). Two experiments at sea were

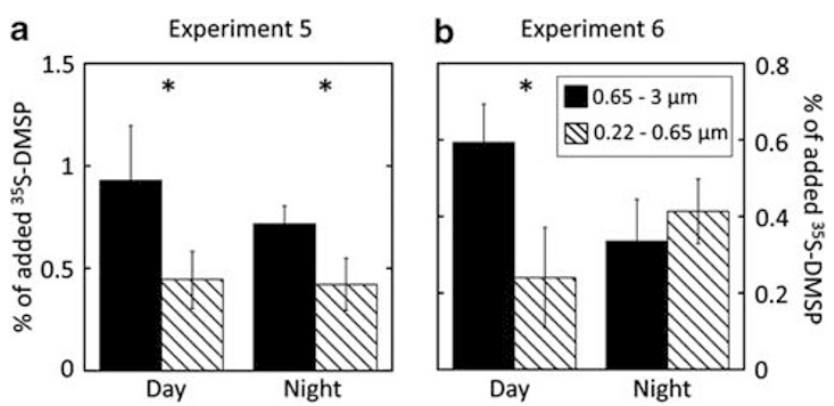

Figure 6 Experiments 5 (a) and 6 (b). Day- and night-averaged percentages of assimilated ${ }^{35}$ S-DMSP by organisms sized $0.65-$ $3 \mu \mathrm{m}$ (black bars) and $0.22-0.65 \mu \mathrm{m}$ (dashed bars) as measured every $4 \mathrm{~h}$ during a $24 \mathrm{~h}$ cycle. Values are mean \pm standard errors of 3-4 data points. * Significant differences between both size fractions (analysis of variance (ANOVA), $P<0.05$ ).

carried out during $24 \mathrm{~h}$ cycles, one in shelf waters (exp. 5) and the other in open-sea waters (exp. 6). Incubations were done under natural full sunlight conditions. No clear patterns were observed throughout the cycles when plotting single data points measured every $4 \mathrm{~h}$ (data not shown); however, when day and night samples were separately averaged for each fraction, we found that during the day, the larger fraction (containing cyanobacteria) assimilated significantly more substrate than the smaller bacterial fraction (analysis of variance, $P<0.05$ ), whereas at night these differences were either lower (cycle 1, Figure 6a) or null (cycle 2, Figure 6b).

\section{Discussion}

It is now recognised that the marine picophytoplankton communities composed of Synechococcus, Prochlorococcus and small eukaryotic phytoplankters dominate the photoautotrophic plankton over vast tracks of the world's oceans. However, whereas their contribution to global primary production is well documented (Waterbury et al., 1986; Partensky et al., 1999), their role in the consumption of dissolved organic compounds, although recognised, has been much less intensely studied (see, for example, Zubkov and Tarran, 2005; Michelou et al., 2007; Mary et al., 2008).

Results from our dark incubation (exp. 1) further confirmed that similarly to heterotrophic bacteria, both Prochlorococcus and Synechococcus may benefit from using a reduced sulphur source such as DMSP, probably because it saves the energy required to reduce the abundant sulphate (Kiene et al., 1999). This is the second study reporting ${ }^{35}$ S-DMSP uptake by a natural Prochlorococcus population, after Vila-Costa et al. (2006). Studies with cultured and natural assemblages of heterotrophic bacteria showed that DMSP and glycine betaine share the same membrane transporter (Kempf and Bremer, 1998; Kiene et al., 1998). 
Putative glycine betaine transporter genes have been found in the genomes of culture representatives of both Prochlorococcus and Synechococcus (Palenik et al., 2003; Rocap et al., 2003), thus supporting the observed capacity of these widespread photosynthetic taxa to take up and assimilate DMSP. We found that the amount of radioisotope incorporated per cyanobacterial cell was larger than that per heterotrophic bacterium, consistent with their larger size. On a per biovolume (proxy to biomass) basis, and in agreement with the observations of Vila-Costa et al. (2006), heterotrophic bacteria were the most efficient at incorporating DMSP, although they were closely followed by Synechococcus and, to a lesser extent, by Prochlorococcus. As the sample was collected in the night and it was incubated in the absence of light, it is likely that the observed uptake efficiencies among the studied groups may change in the presence of light because the cyanobacterial heterotrophic uptake of DMSP can be stimulated upon illumination, as suggested by the present and previous works (Malmstrom et al., 2005; Vila-Costa et al., 2006).

Although often considered ecologically unimportant, recent studies indicate that cyanobacterial photoheterotrophy might significantly influence the flux of dissolved organic matter in the euphotic zone of marine ecosystems. As an example, Church et al. $(2004,2006)$ attributed their observed light enhancement of bacterial production to Prochlorococcus photoheterotrophy in the North Pacific gyre, and these same organisms were also responsible for $\sim 30 \%$ of methionine turnover in the Arabian Sea (Zubkov et al., 2003). Likewise, some Synechococcus have been shown to assimilate amino acids (Willey and Waterbury, 1989; Paerl, 1991), yet their contribution to methionine uptake was lower than that of Prochlorococcus in the Arabian Sea (Zubkov et al., 2003).

By using flow cytometry cell sorting (exp. 2), we found that exposure to diverse sunlight treatments caused differential effects on Synechococcus and heterotrophic bacteria. These two groups had been previously studied in Blanes Bay with regard to their UVR sensitivities. Heterotrophic bacterial activity is generally negatively affected by UVR (Herndl et al., 1993; Sommaruga et al., 1997), although this varies among bacterial taxa (Alonso-Sáez et al., 2006), whereas Synechococcus exhibit high resistance (Sommaruga et al., 2005). In agreement with the previous observations, we found that upon PAR and particularly full sunlight exposure, heterotrophic bacteria were inhibited in their ${ }^{35} \mathrm{~S}$-DMSP uptake whereas Synechococcus were not. Consequently, the relative role of Synechococcus as a DMSP sink became more important under full solar radiation than under dark conditions (Figure 2). Furthermore, on a per-cell volume basis, Synechococcus cells equalled the amount of radioisotope incorporated by heterotrophic bacteria (Figure 3), suggesting an important role of sunlight in regulating the fate of dissolved DMSP and the physiological use of DMSP-sulphur.

Interestingly, we observed that the fraction of assimilated ${ }^{35}$ S-DMSP not associated with Synechococcus or heterotrophic bacteria showed a greater contribution to total uptake toward the full sunlight spectrum (up to $75 \%$, Figure 2a). We have no direct hint of which organisms may be responsible for this large proportion of ${ }^{35} \mathrm{~S}-\mathrm{DMSP}$ assimilation; Vila-Costa et al. (2006) and Ruiz-González et al. (submitted) have reported notable uptake activity by large eukaryotic phytoplankton, particularly diatoms. Actually, the amount of ${ }^{35} \mathrm{~S}$-DMSP assimilated by the unknown organisms increased with PAR and PAR + UVA and decreased with respect to those treatments under full sunlight (data not shown), a response similar to that observed in polar diatoms by Ruiz-González et al. (submitted). This suggests an important role of eukaryotic organisms in the DMSP fluxes, which still deserves further research.

Assimilation of ${ }^{3} \mathrm{H}$-leucine was simultaneously measured for comparative purposes as leucine is considered a universal substrate for heterotrophic bacteria (Kirchman et al., 1985) that can also be incorporated by cyanobacteria (Kamjunke and Jähnichen, 2000; Mary et al., 2008). Unlike with ${ }^{35} \mathrm{~S}$-DMSP-amended samples, solar radiation did not seem to alter the relative contributions of both heterotrophic bacteria and cyanobacteria to ${ }^{3} \mathrm{H}-\mathrm{leu}-$ cine uptake (Figure 2d). There are studies showing that light can stimulate the uptake of amino acids by phototrophic organisms (Zubkov and Tarran, 2005; Michelou et al., 2007; Mary et al., 2008), but none studied the process in the presence of UVR.

MAR-CARD-FISH allowed for a visual analysis of the single-cell uptake activity of both Bacteria and Synechococcus from Blanes Bay in exps. 3 and 4 . As a result of light exposure, the relative contribution of Synechococcus to the number of ${ }^{35}$ S-DMSP-assimilating cells strongly increased, whereas that of heterotrophic bacteria either decreased upon UVR exposure (exp. 3, early July) or increased, but less than Synechococcus (exp. 4, late September). Moreover, in spite of their low abundances, active Synechococcus accounted for 15\% (exps. 3 and 4) of active Bacteria under full sunlight, a proportion comparable to those observed for other major bacterial groups in diverse ecosystems (Vila et al., 2004; Malmstrom et al., 2004b; Vila-Costa et al., 2007), and for Synechococcus in the Northwest Atlantic and the Gulf of Mexico (Malmstrom et al., 2005). Hence, according to this significant assimilation capacity and their widespread distribution (Waterbury et al., 1979), Synechococcus are likely to be an important sink for marine DMSP. Interestingly, a higher contribution of Synechococcus was observed in exp. 3 than in exp. 4, in accordance with higher UVB doses measured in the former (Table 1). Yet, any hypothesis about Synechococcus heterotrophy dependence on irradiance levels remains to be 
tested. Once again, this pattern was not reflected in ${ }^{3}$ H-leucine uptake. Only in exp. 3, Synechococcus seemed to respond to light changes, showing an increase in the proportion of active cells upon PAR exposure and a further decrease when UVR was included. This light stimulation of ${ }^{3} \mathrm{H}$-leucine uptake by Synechococcus has been recently observed at the BBMO across different seasons except autumn, and hence has the corresponding UVR-induced inhibition, which was stronger in the spring and summer periods coinciding with higher UVR doses (Ruiz-González, unpublished). Despite the higher percentages of ${ }^{3} \mathrm{H}$ leucine-assimilating Synechococcus cells found in our light incubations, their contribution to total active Bacteria was never higher than 3\%. Altogether, these results indicate that heterotrophy in Synechococcus is strongly dependent not only on sunlight spectrum and maybe intensity, but also on the type of substrate considered.

Shipboard exps. 5 and 6 served to further explore the potential osmoheterotrophic competition between cyanobacteria and heterotrophic bacteria at the sub-daily scale. Over the two $24 \mathrm{~h}$ periods, a trend toward higher ${ }^{35} \mathrm{~S}-\mathrm{DMSP}$ assimilation by the cyanobacteria-containing, larger picoplankton fraction (that is, $0.65-3 \mu \mathrm{m}$ ) was found during the light hours, whereas at night, it was more evenly distributed between the two size fractions. Interestingly, in most cases, the average ${ }^{35} \mathrm{~S}$-DMSP assimilation in the $0.65-3 \mu \mathrm{m}$ fraction was significantly higher than that in the $0.22-0.65 \mu \mathrm{m}$ fraction, pointing to a more important contribution of picophytoplankton (and maybe attached bacteria) than that of free-living heterotrophic bacteria to total DMSP-sulphur assimilation. However, size fractionation is an inaccurate method to assess the distribution of assimilation owing to imperfect size segregation, inclusion of detritus and overlook of bacterial aggregates. Furthermore, the larger fraction included, beside cyanobacteria, picoeukaryotic cells that could have also assimilated ${ }^{35}$ S-DMSP (VilaCosta et al., 2006) or could have ingested labelled bacteria. Whether these complementary players also respond positively to light is unknown. In any case, these results support the aforementioned observations at the single-cell level that light shifts DMSPsulphur assimilation away from the clear dominance of heterotrophic bacteria usually found in dark incubations.

As a photosynthetic cell, Synechococcus is subjected to diel variations in energy supply over the light/dark cycle, and many physiological processes, such as specific enzyme transcription, DNA synthesis or cell division, are coupled to this periodicity (Wyman, 1999; Jacquet et al., 2001). Hence, diel variations in Synechococcus and other picophytoplankters' activities are expected to result in shifts in the relative dominance of phototrophs versus heterotrophs in the uptake of DMSP-sulphur throughout the light/dark cycle. Additionally, similar shifts may also occur at the seasonal scale.
Considering that in Blanes Bay, both the highest concentrations of dissolved DMSP (Vila-Costa et al., 2008a) and the maximum abundances of Synechococcus (Agawin et al., 1998; Schauer et al., 2003) occur in the highly irradiated waters of late spring and summer, one might expect competition between cyanobacteria and heterotrophic bacteria (and possibly larger phototrophs; Vila-Costa et al., 2006) for DMSP-sulphur to be maximal in summer and minimal in autumn and winter.

Overall, our results confirm that marine, free-living, unicellular cyanobacteria (that is, Prochlorococcus and Synechococcus) from the Mediterranean Sea are able to take up DMSP and assimilate its sulphur, and all our different experimental approaches agreed with an increased contribution of Synechococcus and probably some picoeukaryotes to ${ }^{35} \mathrm{~S}-\mathrm{DMSP}$ uptake relative to heterotrophic bacteria under light exposure compared with dark conditions. These results suggest that the DMSP dynamics in oceanic surface waters are severely influenced by solar UVR through differential inhibition or stimulation of the microbial consortia responsible for most of the DMSP consumption. Our findings stress the generally overlooked role of phytoplankton as DMSP consumers under realistic light conditions and the need for further research. Interestingly, the pronounced effects of the lightdriven activation of Synechococcus did not show up in the uptake of ${ }^{3} \mathrm{H}$-leucine. Determining the reasons for this differential regulation of substrate uptake by light may help better understand and predict the microbial use of labile dissolved organic matter in the surface ocean.

\section{Acknowledgements}

We thank C Cardelús, V Balagué, I Forn and all the people participating in the Blanes Bay program for help with sampling and sample processing. We also thank scientists, technicians and crew on board the RV 'García del Cid' for their help and good mood, and J Felipe and E Blanch for their valuable help with the cell sorting analysis, D Slezak for assistance with experiment 2 and M Galí, who helped with irradiance data. This work was supported by the European Union through project BASICS (EVK3-CT-200200078) and by the Spanish Ministry of Science and Innovation through projects MODIVUS (CTM200504795/MAR) and SUMMER (CTM2008-03309/MAR).

\section{References}

Agawin NSR, Duarte CM, Agustí S. (1998). Growth and abundance of Synechococcus sp. in a Mediterranean Bay: seasonality and relationship with temperature. Mar Ecol Prog Ser 170: 45-53.

Alonso-Sáez L, Gasol JM, Lefort T, Hofer J, Sommaruga R. (2006). Effect of natural sunlight on bacterial activity and differential sensitivity of natural bacterioplankton groups in northwestern Mediterranean coastal waters. Appl Environ Microbiol 72: 5806-5813.

Amann RI, Binder BJ, Olson RJ, Chisholm SW, Devereux R, Stahl DA. (1990). Combination of $16 \mathrm{~S}$ rRNA- 
targeted oligonucleotide probes with flow cytometry for analyzing mixed microbial populations. Appl Environ Microbiol 56: 1919-1925.

Andreae MO, Crutzen PJ. (1997). Atmospheric aerosols: biogeochemical sources and role in atmospheric chemistry. Science 276: 1052-1058.

Archer SD, Ragni M, Webster R, Airs RL, Geiderb RJ. (2010). Dimethyl sulfoniopropionate and dimethyl sulfide production in response to photoinhibition in Emiliania huxleyi. Limnol Oceanogr 55: 1579-1589.

Archer SD, Stelfox-Widdicombe CE, Malin G, Burkill PH. (2003). Is dimethyl sulphide production related to microzooplankton herbivory in the southern North Sea? J Plankton Res 25: 235-242.

Bates TS, Lamb BK, Guenther A, Dignon J, Stoiber RE. (1992). Sulfur emissions to the atmosphere from natural sources. J Atmos Chem 14: 315-337.

Charlson RJ, Lovelock JE, Andreae MO, Warren SG. (1987). Oceanic phytoplankton, atmospheric sulfur, cloud albedo and climate. Nature 326: 655-661.

Church MJ, Ducklow HW, Karl DA. (2004). Light dependence of $\left[{ }^{3} \mathrm{H}\right]$ leucine incorporation in the oligotrophic North Pacific ocean. Appl Environ Microbiol 70: 4079-4087.

Church MJ, Ducklow HW, Letelier RM, Karl DM. (2006). Temporal and vertical dynamics in picoplankton photoheterotrophic production in the subtropical North Pacific Ocean. Aquat Microb Ecol 45: 41-53.

Cunningham GB, Strauss V, Ryan PG. (2008). African penguins (Spheniscus demersus) can detect dimethyl sulphide, a prey-related odour. J Exp Biol 211: 3123-3127.

Dacey JWH, Wakeham SG. (1986). Oceanic dimethylsulfide: production during zooplankton grazing on phytoplankton. Science 233: 1314-1316.

Daims H, Bruhl A, Amann R, Schleifer KH, Wagner M. (1999). The domain-specific probe EUB338 is insufficient for the detection of all Bacteria: development and evaluation of a more comprehensive probe set. Syst Appl Microbiol 22: 434-444.

DeBose JL, Lema SC, Nevitt GA. (2008). Dimethylsulfoniopropionate as a foraging cue for reef fishes. Science 319: 1356-1356.

González JM, Kiene RP, Moran MA. (1999). Transformation of sulfur compounds by an abundant lineage of marine bacteria in the alpha-subclass of the class Proteobacteria. Appl Environ Microbiol 65: 3810-3819.

Herndl GJ, Müller-Niklas G, Frick J. (1993). Major role of ultraviolet $\mathrm{B}$ in controlling bacterioplankton growth in the surface layer of the ocean. Nature 361: 717-719.

Howard EC, Henriksen JR, Buchan A, Reisch CR, Buergmann H, Welsh R et al. (2006). Bacterial taxa that limit sulfur flux from the ocean. Science 314: 649-652.

Jacquet S, Partensky F, Lennon JF, Vaulot D. (2001). Diel patterns of growth and division in marine picoplankton in culture. J Phycol 37: 357-369.

Kamjunke N, Jähnichen S. (2000). Leucine incorporation by Microcystis aeruginosa. Limnol Oceanogr 45: 741-743.

Kempf B, Bremer E. (1998). Uptake and synthesis of compatible solutes as microbial stress responses to high-osmolality environments. Arch Microbiol 170: 319-330.

Kettle AJ, Andreae MO, Amouroux D, Andreae TW, Bates TS, Berresheim H et al. (1999). A global database of sea surface dimethylsulfide (DMS) measurements and a procedure to predict sea surface DMS as a function of latitude, longitude, and month. Global Biogeochem $C y$ 13: $399-444$

Kiene RP, Linn LJ, Bruton JA. (2000). New and important roles for DMSP in marine microbial communities. J Sea Res 43: 209-224.

Kiene RP, Linn LJ, Gonzalez J, Moran MA, Bruton JA. (1999). Dimethylsulfoniopropionate and methanethiol are important precursors of methionine and proteinsulfur in marine bacterioplankton. Appl Environ Microbiol 65: 4549-4558.

Kiene RP, Williams LPH, Walker JE. (1998). Seawater microorganisms have a high affinity glycine betaine uptake system which also recognizes dimethylsulfoniopropionate. Aquat Microb Ecol 15: 39-51.

Kirchman D, Knees E, Hodson R. (1985). Leucine incorporation and its potential as a measure of protein-synthesis by bacteria in natural aquatic systems. Appl Environ Microbiol 49: 599-607.

Lovelock JE, Maggs RJ, Rasmussen RA. (1972). Atmospheric dimethyl sulfide and natural sulfur cycle. Nature 237: 452-453.

Malmstrom RR, Kiene RP, Cottrell MT, Kirchman DL. (2004a). Contribution of SAR11 bacteria to dissolved dimethylsulfoniopropionate and amino acid uptake in the North Atlantic Ocean. Appl Environ Microbiol 70: 4129-4135.

Malmstrom RR, Kiene RP, Kirchman DL. (2004b). Identification and enumeration of bacteria assimilating dimethylsulfoniopropionate (DMSP) in the North Atlantic and Gulf of Mexico. Limnol Oceanogr 49: 597-606.

Malmstrom RR, Kiene RP, Vila M, Kirchman DL. (2005). Dimethylsulfoniopropionate (DMSP) assimilation by Synechococcus in the Gulf of Mexico and northwest Atlantic Ocean. Limnol Oceanogr 50: 1924-1931.

Mary I, Tarran GA, Warwick PE, Terry MJ, Scanlan DJ, Burkill PH et al. (2008). Light enhanced amino acid uptake by dominant bacterioplankton groups in surface waters of the Atlantic Ocean. FEMS Microbiol Ecol 63: 36-45.

Michelou VK, Cottrell MT, Kirchman DL. (2007). Lightstimulated bacterial production and amino acid assimilation by cyanobacteria and other microbes in the North Atlantic Ocean. Appl Environ Microbiol 73: 5539-5546.

Nevitt GA. (2008). Sensory ecology on the high seas: the odor world of the procellariiform seabirds. J Exp Biol 211: 1706-1713.

Paerl HW. (1991). Ecophysiological and trophic implications of light-stimulated amino acid utilization in marine picoplankton. Appl Environ Microbiol 57: 473-479.

Palenik B, Brahamsha B, Larimer FW, Land M, Hauser L, Chain $\mathrm{P}$ et al. (2003). The genome of a motile marine Synechococcus. Nature 424: 1037-1042.

Partensky F, Hess WR, Vaulot D. (1999). Prochlorococcus, a marine photosynthetic prokaryote of global significance. Microbiol Mol Biol Rev 63: 106-127.

Pernthaler A, Pernthaler J, Amann R. (2002). Fluorescence in situ hybridization and catalyzed reporter deposition for the identification of marine bacteria. Appl Environ Microbiol 68: 3094-3101.

Rocap G, Larimer FW, Lamerdin J, Malfatti S, Chain P, Ahlgren NA et al. (2003). Genome divergence in two Prochlorococcus ecotypes reflects oceanic niche differentiation. Nature 424: 1042-1047. 
Ruiz-González C, Galí M, Gasol JM, Simó R. (2011). Sunlight effects on DMSP-sulfur and leucine assimilation activities of polar heterotrophic bacterioplankton. Biogeochemistry (in press).

Ruiz-González C, Galí M, Sintes E, Herndl GJ, Gasol JM, Simó R. Sunlight effects on the osmoheterotrophic behaviour of Arctic and Antarctic phytoplankton. Environ Microbiol (submitted).

Saló V, Simó R, Vila-Costa M, Calbet A. (2009). Sulfur assimilation by Oxyrrhis marina feeding on a ${ }^{35} \mathrm{~S}$ DMSP-labelled prey. Environ Microbiol 11: 3063-3072.

Schauer M, Balagué V, Pedrós-Alió C, Massana R. (2003). Seasonal changes in the taxonomic composition of bacterioplankton in a coastal oligotrophic system. Aquat Microb Ecol 31: 163-174.

Seymour JR, Simó R, Ahmed T, Stocker R. (2010). Chemoattraction to dimethylsulfoniopropionate throughout the marine microbial food web. Science 329: 342-345.

Simó R. (2001). Production of atmospheric sulfur by oceanic plankton: biogeochemical, ecological and evolutionary links. Trends Ecol Evol 16: 287-294.

Simó R, Archer SD, Pedrós-Alió C, Gilpin L, StelfoxWiddicombe CE. (2002). Coupled dynamics of dimethylsulfoniopropionate and dimethylsulfide cycling and the microbial food web in surface waters of the North Atlantic. Limnol Oceanogr 47: 53-61.

Slezak D, Brugger A, Herndl GJ. (2001). Impact of solar radiation on the biological removal of dimethylsulfoniopropionate and dimethylsulfide in marine surface waters. Aquat Microb Ecol 25: 87-97.

Slezak D, Herndl GJ. (2003). Effects of ultraviolet and visible radiation on the cellular concentrations of dimethylsulfoniopropionate (DMSP) in Emiliania huxleyi (strain L). Mar Ecol Prog Ser 246: 61-71.

Slezak D, Kiene RP, Toole DA, Simo R, Kieber DJ. (2007). Effects of solar radiation on the fate of dissolved DMSP and conversion to DMS in seawater. Aquat Sci 69: 377-393.

Sommaruga R, Hofer JS, Alonso-Sáez L, Gasol JA. (2005). Differential sunlight sensitivity of picophytoplankton from surface Mediterranean coastal waters. Appl Environ Microbiol 71: 2154-2157.

Sommaruga R, Obernosterer I, Herndl GJ, Psenner R. (1997). Inhibitory effect of solar radiation on thymidine and leucine incorporation by freshwater and marine bacterioplankton. Appl Environ Microbiol 63: 4178-4184.

Stefels J. (2000). Physiological aspects of the production and conversion of DMSP in marine algae and higher plants. J Sea Res 43: 183-197.

Sunda W, Kieber DJ, Kiene RP, Huntsman S. (2002). An antioxidant function for DMSP and DMS in marine algae. Nature 418: 317-320.

Tang KW, Simó R. (2003). Trophic uptake and transfer of DMSP in simple planktonic food chains. Aquat Microb Ecol 31: 193-202.

Van Alstyne KL, Wolfe GV, Freidenburg TL, Neill A, Hicken C. (2001). Activated defense systems in marine macroalgae: evidence for an ecological role for DMSP cleavage. Mar Ecol Prog Ser 213: 53-65.
Vila M, Simó R, Kiene RP, Pinhassi J, González JA, Moran MA et al. (2004). Use of microautoradiography combined with fluorescence in situ hybridization to determine dimethylsulfoniopropionate incorporation by marine bacterioplankton taxa. Appl Environ Microbiol 70: 4648-4657.

Vila-Costa M, Kiene RP, Simó R. (2008a). Seasonal variability of the dynamics of dimethylated sulfur compounds in a coastal northwest Mediterranean site. Limnol Oceanogr 53: 198-211.

Vila-Costa M, Pinhassi J, Alonso C, Pernthaler J, Simó R. (2007). An annual cycle of dimethylsulfoniopropionate-sulfur and leucine assimilating bacterioplankton in the coastal NW Mediterranean. Environ Microbiol 9: 2451-2463.

Vila-Costa M, Simó R, Alonso-Sáez L, Pedrós-Alió C. (2008b). Number and phylogenetic affiliation of bacteria assimilating dimethylsulfoniopropionate and leucine in the ice-covered coastal Arctic Ocean. J Mar Syst 74: 957-963.

Vila-Costa M, Simó R, Harada H, Gasol JM, Slezak D, Kiene RP. (2006). Dimethylsulfoniopropionate uptake by marine phytoplankton. Science 314: 652-654.

Waterbury JB, Watson SW, Guillard RRL, Brand LE. (1979). Widespread occurrence of a unicellular, marine, planktonic cyanobacterium. Nature 277: 293-294.

Waterbury JB, Watson SW, Valois FW, Franks DG. (1986). Biological and ecological characterisation of the marine unicellular cyanobacterium Synechococcus. In Platt T, Li WKW (eds), Photosynthetic Picoplankton Can Bull Fish Aquat Sci Vol 214: 71-120.

West NJ, Schonhuber WA, Fuller NJ, Amann RI, Rippka R, Post AF et al. (2001). Closely related Prochlorococcus genotypes show remarkably different depth distributions in two oceanic regions as revealed by in situ hybridization using 16S rRNA-targeted oligonucleotides. Microbiology 147: 1731-1744.

Willey JM, Waterbury JB. (1989). Chemotaxis toward nitrogenous compounds by swimming strains of marine Synechococcus spp. Appl Environ Microbiol 55: $1888-1894$.

Wyman M. (1999). Diel rhythms in ribulose-1,5-bisphosphate carboxylase/oxygenase and glutamine synthetase gene expression in a natural population of marine picoplanktonic cyanobacteria (Synechococcus spp.). Appl Environ Microbiol 65: 3651-3659.

Zubkov MV, Fuchs BM, Archer SD, Kiene RP, Amann R, Burkill PH. (2002). Rapid turnover of dissolved DMS and DMSP by defined bacterioplankton communities in the stratified euphotic zone of the North Sea. DeepSea Res Pt II 49: 3017-3038.

Zubkov MV, Fuchs BM, Tarran GA, Burkill PH, Amann R. (2003). High rate of uptake of organic nitrogen compounds by Prochlorococcus cyanobacteria as a key to their dominance in oligotrophic oceanic waters. Appl Environ Microbiol 69: 1299-1304.

Zubkov MV, Tarran GA. (2005). Amino acid uptake of Prochlorococcus spp. in surface waters across the South Atlantic Subtropical Front. Aquat Microb Ecol 40: $241-249$. 